Journal of Environmental Engineering and Science

Volume 10 Issue JS3

A well site reclamation prioritisation model framework

Thiessen and Achari
Journal of Environmental Engineering and Science, 2015, 10(3), 62-72 http://dx.doi.org/10.1680/jees.15.00007

\title{
A well site \\ reclamation prioritisation model framework
}

Ron J. Thiessen MSc(Eng), PEng, EP

Doctoral Candidate, Schulich School of Engineering, University of Calgary, Calgary, Alberta, Canada
Gopal Achari PhD, PEng

Professor, Schulich School of Engineering, University of Calgary, Calgary, Alberta, Canada

There are approximately 60000 oil and gas well sites in Alberta that are abandoned but not reclaimed. This number is growing at approximately $10 \%$ per year. Currently, there is no regulatory requirement to reclaim well sites within a defined period after abandonment. The government regulator is reviewing this issue and is considering options to improve timely reclamation. In preparation for this change, the article provides the structure of a model to prioritise oil and gas well site reclamation across a portfolio of sites according to negative environmental, social and economic impacts. Adverse environmental receptor effects, adverse public response, environmental liability and property value diminution are used to quantify these impacts. Ordinal logistic regression and partial order methods to classify and rank well sites are applied in the model. A case study illustrates the prioritisation model.

\section{Notation}

$a, b, c, d, e, f$ context-specific; refer to text

AE adverse receptor effect

Att set of attributes

$\mathbf{A t t}_{\mathbf{m}} \quad$ subset of attributes

$\mathrm{C}_{\mathrm{AE}} \quad$ adverse receptor effect class

$\mathrm{C}_{\mathrm{att}} \quad$ class of an attribute

$\mathrm{C}_{\mathrm{EL}} \quad$ environmental liability class

$\mathrm{C}_{\mathrm{h}_{\mathrm{jk}}} \quad$ hazard index class

$\mathrm{C}_{\mathrm{k}} \quad$ receptor presence class

$\mathrm{C}_{\mathrm{p}_{\mathrm{jk}}} \quad$ pathway operability class

$\mathrm{C}_{\mathrm{PR}} \quad$ adverse public response class

$\mathrm{C}_{\mathrm{PVD}} \quad$ property value diminution class

$\mathrm{C}_{\mathrm{s}} \quad$ well site class

h hazard

HI hazard index

$\mathrm{HI}_{\mathrm{jk}} \quad$ contaminant and receptor-specific HI

inc $(a) \quad$ incomparable; see explanation for Equation 10

j contaminant

$\mathrm{k} \quad$ receptor

$\mathrm{N}_{\text {att }} \quad$ number of attributes

$\mathrm{N}_{\mathrm{s}} \quad$ number of sites

$\mathrm{p} \quad$ contaminant pathway

$\mathrm{p}\left(\mathrm{C}_{\mathrm{att}}\right) \quad$ probability of an attribute being in a given class

Quo $_{\text {att }}$ quotient for an attribute

$\mathrm{Rk}_{\mathrm{av}}(a) \quad$ average rank of $a$

$\mathrm{Rk}_{\max }(a)$ maximum rank of $a$

$\mathrm{Rk}_{\text {min }}(a)$ minimum rank of $a$

$\sup (a) \quad$ superior; see explanation for Equation 10

UF uncertainty factor

$\Delta \mathrm{C}_{\mathrm{AE}_{\mathrm{k}}} \quad$ change in adverse receptor effect class
$\Delta \mathrm{C}_{\text {att }} \quad$ represents $\Delta \mathrm{C}_{\mathrm{AE}_{\mathrm{k}}}, \Delta \mathrm{C}_{\mathrm{PR}}$, or $\Delta \mathrm{C}_{\mathrm{PVD}}$ depending on context

$\Delta \mathrm{C}_{\mathrm{EL}} \quad$ change in environmental liability class

$\Delta \mathrm{C}_{\mathrm{PR}} \quad$ change in adverse public response class

$\Delta \mathrm{C}_{\mathrm{PVD}} \quad$ change in property value diminution class

\section{Introduction}

\section{Background}

In Alberta, over 60000 oil and gas wells are no longer in production (i.e. abandoned) and not yet restored to a pre-development state (AEP, 2015). This restoration process, called reclamation, involves remediating soil and groundwater contamination associated with an abandoned well and then returning the site to an equivalent capability of surrounding lands in terms of vegetation, soil quality and landscape (AER, 2014a). The number of such well sites is growing at approximately $10 \%$ per year (AEP, 2015). Currently, there is no regulatory requirement to reclaim well sites within a defined period after well production ceases (Robinson, 2010; Unger, 2013). However, Alberta's environmental protection regulator is reviewing this issue and is considering options to improve timely reclamation (ESRD, 2015). It is understood that reclaiming all well sites at once is practically impossible. Thus, once reclamation timelines are defined, well site operators (i.e. licensees) who own hundreds of well sites will need a plan to prioritise the backlog of unreclaimed sites.

This paper presents a framework of a model to prioritise oil and gas well sites for reclamation. It takes a holistic approach and considers the negative social, environmental and economic impacts of unreclaimed well sites. These three dimensions are crucial when 
evaluating an organisation's social responsibility in decision making (ISO, 2010). The model accomplishes the following

1. defines measures, quantification and inter-relationships of negative environmental, economic and social impacts associated with unreclaimed well sites

2. provides estimates of the negative environmental, economic and social impacts of an unreclaimed well site

3. incorporates these estimates into a prioritisation system for well site reclamation.

A description of negative environmental, social and economic impacts is presented below.

\section{Negative environmental impact}

A primary concern regarding unreclaimed well sites is the detrimental environmental consequences they cause, which are called adverse effects. The presence of adverse effect at a well site is determined, in part, from the landscape, vegetation and soils assessments conducted as part of surface reclamation efforts (ESRD, 2013). Significant adverse effects may occur when contaminant hazards and biological receptors (e.g. humans, animals or vegetation) become connected by means of exposure pathways (NEB, 2014)

Focusing on the remediation part of reclamation, preliminary quantitative risk assessment (PQRA) is a common tool for estimating adverse effect to human and ecological receptors (CEAA, 2012). Contaminant types, mass, distribution; environmental media contaminated; and terrestrial and biological receptors affected by the contaminants are evaluated to estimate adverse receptor effect. The Canadian Council of Ministers of the Environment (CCME, 1996, 1997) and Environment Canada (2012) define the structure and protocols of ecological risk assessments. Similarly, Health Canada (2010, 2011) establishes the structure and procedures of human health risk assessments. The Canadian Council of Ministers of the Environment (CCME, 2006a, 2015) provides guidance on how to derive environmental quality guidelines, a specific form of PQRA, which are protective of human and ecological receptors.

\section{Negative social impact}

Environmental hazard perception is an individual's or community's impression of the hazards posed by a contaminated site. Intuitive toxicology was a term used by Kraus et al. (1992) to describe the general public's understanding of chemical risks. In comparisons of scientific and intuitive toxicology, Kraus et al. (1992), Krewski et al. (2012), Mertz et al. (1998), Neil et al. (1994) and Slovic et al. (1995) investigated differences between experts' and the public's views on risks posed by chemicals. A theme across their findings was confirmation that the public is often more risk averse than experts.

Lazo et al. (2000) identified four latent factors that influence hazard perception: impact, control, acceptance and understanding. Impact considers the number of people or size of area affected, how severe the adverse effect can be, and the period over which the adverse effect will last. Control describes the degree to which an individual or community can avoid or mitigate the risk. Acceptance considers whether society will benefit from accepting the hazard or whether an ecosystem will adapt to the hazard. Understanding is the perceived level of knowledge that laypersons and experts have about the hazard and its effects. Thiessen and Achari (2014) summarised the work of Lazo et al. (2000) in the context of contaminated sites.

Adverse public response is the measurable, negative social impact of the latent perception factors. Kasperson et al. (2003) listed financial loss, regulatory action, complaints and loss of trust as examples of adverse public response.

\section{Negative economic impact}

The environmental liability caused by an unreclaimed well site is a negative economic impact. CCME (2006b) defines two central concepts underlying environmental liability. The polluter-pays concept is that the party "who is responsible for a contaminant release to the environmental is also liable for removing the contamination to restore the site' (CCME, 2006b). In addition, the beneficiary-pays concept is that the party 'who benefited from the activity resulting in the contamination should share liability for its cleanup with other responsible persons' (CCME, 2006b). A well site licensee can be both the polluter and the beneficiary.

Canadian accounting guidance for non-governmental, publicly accountable organisations defines environmental liability using an example: 'a liability is a present obligation ... Examples of such obligations are penalties or clean-up costs for unlawful environmental damage' (CPA, 2014). Alberta's energy regulator elaborates on this definition by requiring environmental liability estimates to be based on reclamation methods proven effective in achieving reclamation guidelines that permit unrestricted, equivalent land use to that prior to the industrial development (ERCB, 2012). Estimates must be what a licensee would 'rationally pay' (CPA, 2014) to meet reclamation guidelines.

Reduced property value or function due to contamination is another negative economic impact. In real estate appraisal, a detrimental condition is any property-related condition that negatively affects property value (Bell et al., 2008). Property value diminution (PVD) due to the detrimental condition is the unimpaired property value minus impaired property value. PVD caused by contamination is divided into three types: cost, use and risk (AIC, 2010)

- 'Cost effects: deductions for costs to remediate a contaminated property to appropriate regulatory standards, recognising that not all costs are recognised by the market as having an effect on value.'

- 'Use effects: limitations on the highest and best use of properties that may be impacted by environmental contamination, recognising that these effects would be meaningful only if they limited the use of the site or property that would be the highest and best use without the effect of the contamination, and would 
otherwise meet the four highest and best use criteria (i.e. physically possible, legally permissible, financially feasible, and maximally productive).'

- 'Risk effects: the effects on value due to increased perceptions of environmental risk by relevant market participants'

(AIC, 2010)

Cost effects are related to environmental liability but do not necessarily equate to the dollar value assigned to the environmental liability for a site. The risk effect portion of contaminated site valuation is also called environmental stigma: 'an adverse effect on property value produced by the market's perception of increased environmental risk due to contamination' (AIC, 2010; ASB, 2013). In the appraisal profession, environmental risk is the potential downside of having a financial interest in a contaminated site (ASB, 2013).

\section{Methods}

\section{Dimensions and attributes}

Figure 1 presents a cognitive map depicting the inter-relationships of negative environmental, social and economic impacts of unreclaimed well sites and is the framework underlying the well site reclamation prioritisation model. The figure shows the four attribute groups discussed in the previous section: adverse receptor effect, adverse public response, environmental liability and PVD. The inputs to these attribute groups are described as necessary below.

\section{Attribute quantification}

In the model, the four attributes are quantified using a four-class system described as follows. Adverse receptor effect, AE, occurs when both a hazard, $\mathrm{h}$, and a receptor, $\mathrm{k}$, are present and a contaminant pathway, $\mathrm{p}$, connects the hazard to the receptor: $\mathrm{AE}=\mathrm{h}$ $\cap \mathrm{k} \cap \mathrm{p}$. PQRA using the hazard index (HI) approach is applied to estimate whether contaminants were hazardous. The HI is the maximum measured or predicted dosage or concentration of a contaminant divided by a reference dose or concentration for a specified receptor or receptor group and contaminant, j. The CCME (2006a, 2015), Environment Canada (2012), Alberta Environment and Sustainable Resource Development (ESRD, 2014), and Health Canada (2010) provide PQRA guidance. A hazard index, $\mathrm{HI}_{\mathrm{jk}}$, is calculated for each contaminant-receptor combination and the result compared to the thresholds shown on the right-hand side of the inequalities in Equation 1 to categorise the hazard into one of four classes, $\mathrm{C}_{\mathrm{h}_{\mathrm{j}}}$. The abbreviation UF is the contaminant-specific and receptor-specific uncertainty factor that was applied by Health Canada, Environment Canada, CCME, or others when reference doses or concentrations were derived.

$$
\mathrm{C}_{\mathrm{h}_{\mathrm{jk}}}=\left\{\begin{array}{c}
1 \text { if } \mathrm{HI}_{\mathrm{jk}} \leq 1 \\
2 \text { if } \mathrm{HI}_{\mathrm{jk}} \leq \sqrt{\mathrm{UF}} \\
3 \text { if } \mathrm{HI}_{\mathrm{jk}} \leq \mathrm{UF} \\
4 \text { if } \mathrm{HQ}_{\mathrm{jk}}>\mathrm{UF}
\end{array}\right\}
$$

Receptor-presence and pathway-operability class selections follow Equation 2 and Equation 3, respectively. The land-use-specific receptor and pathway assumptions provided by Alberta Environment and Sustainable Resource Development (ESRD, 2014) are used to guide class selections.

$$
\mathrm{C}_{\mathrm{k}}=\left\{\begin{array}{c}
1 \text { if receptor not present } \\
3 \text { if receptor potentially present } \\
4 \text { if receptor present }
\end{array}\right\}
$$

$$
\mathrm{C}_{\mathrm{p}_{\mathrm{jk}}}=\left\{\begin{array}{c}
1 \text { if pathway not operational } \\
3 \text { if pathway potentially operational } \\
4 \text { if pathway operational }
\end{array}\right\}
$$

The classes determined from the equations above for each contaminant-receptor pair are then combined using the max-min composition operator (Nguyen and Walker, 2006) in Equation 4, to yield an adverse effect class for a particular receptor, $\mathrm{C}_{\mathrm{AE}_{\mathrm{k}}}$.

$$
\text { 4. } \mathrm{C}_{\mathrm{AE}_{\mathrm{k}}}=\bigvee_{\mathrm{j}}\left(\mathrm{C}_{\mathrm{h}_{\mathrm{jk}}} \wedge \mathrm{C}_{\mathrm{r}_{\mathrm{k}}} \wedge \mathrm{C}_{\mathrm{p}_{\mathrm{jk}}}\right)
$$

Individuals adversely affected by an unreclaimed well site may respond by complaining to the licensee or the government regulator with authority over the licensee. Depending on the circumstances, the regulator may enforce law to resolve the complaint. These possibilities form the classes of adverse public response as organised in Equation 5.

$$
C_{P R}=\left\{\begin{array}{c}
1 \text { if no complaint } \\
2 \text { if complaint to licensee } \\
3 \text { if complaint to regulator } \\
4 \text { if regulatory enforcement }
\end{array}\right\}
$$

The sales comparison approach (AIC, 2010) was selected to estimate PVD. Analysis of covariance (ANCOVA) (Kutner et al., 2005) was chosen to compare sales data for properties without well sites, with abandoned but unreclaimed well sites, and with reclaimed well sites. Referring to Equation 6 , the variables $a, b$ and $c$ are percentages defined a priori by the decision maker, where $a<$ $b<c$. Classes 1-4 correspond to negligible, low, moderate and high PVD, respectively.

$$
\mathrm{C}_{\mathrm{PVD}}=\left\{\begin{array}{l}
1 \text { if } \mathrm{PVD} \leq a \\
2 \text { if } \mathrm{PVD} \leq b \\
3 \text { if } \mathrm{PVD} \leq c \\
4 \text { if } \mathrm{PVD}>c
\end{array}\right\}
$$

Environmental liability estimation was guided by the Chartered Professional Accountants Canada (CPA, 2014) and Alberta 


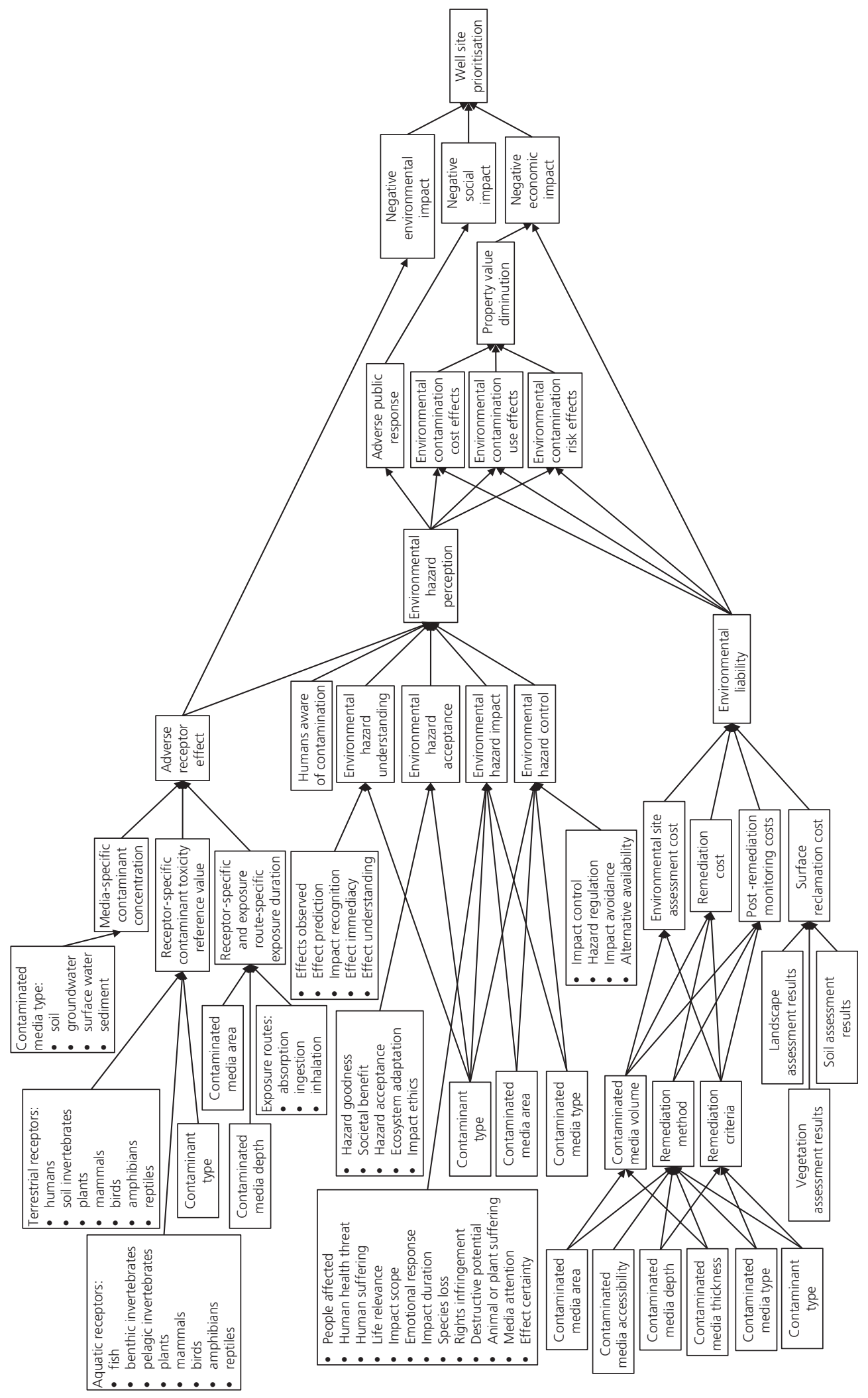




\begin{tabular}{lllll}
\hline Class & Adverse receptor effect & Adverse public response & Environmental liability & PVD \\
\hline 1 & No adverse effect & No complaint & Negligible environmental liability & Negligible PVD \\
2 & Potential adverse effect & Complaint to licensee & Low environmental liability & Low PVD \\
3 & Adverse effect & Complaint to regulator & Moderate environmental liability & Moderate PVD \\
4 & Significant adverse effect & Regulatory enforcement & High environmental liability & High PVD
\end{tabular}

Table 1. Attribute classes

Energy Regulator (AER) (ERCB, 2012). Similar to above, environmental liability (EL) classification is conducted according to Equation 7. The variables $d, e$ and $f$ are dollar values defined by the decision maker, where $d<e<f$. Classes 1-4 correspond to negligible, low, moderate and high environmental liability, respectively.

$$
\mathrm{C}_{\mathrm{EL}}=\left\{\begin{array}{l}
1 \text { if } \mathrm{EL} \leq d \\
2 \text { if } \mathrm{EL} \leq e \\
3 \text { if } \mathrm{EL} \leq f \\
4 \text { if } \mathrm{EL}>f
\end{array}\right\}
$$

Table 1 summarises the attribute quantification discussion above.

\section{Attribute prediction}

Given the defined attribute classes and readily available information, ordinal logistic regression (OLR) models (Hosmer et al., 2013; Norusis, 2007; Tabachnick and Fidell, 2012) were calibrated and validated. Figure 1 was condensed to the predictors and outcomes in Figure 2 and connected by means of OLR models. The outcomes are the attribute classes summarised in Table 1. Well type and well site age provide an indication of contaminant types and hazards. Land use, soil type and population density are estimated from the well site location in Alberta and provide an understanding of exposed receptors and contaminant pathways.

Table 2 lists the levels used for each of the predictors. The well types are as defined by AER (2015). Well site age is the date drilling first occurred on the well site (i.e. spud date) and the three levels are based on the years when significant change occurred in drilling regulations (AER, 2014b, 2014c). Alberta well sites are predominantly on either agricultural land or in undeveloped, natural areas (e.g. forest or grasslands). Coarse as opposed to fine-grained soil correlates to soil permeability, which strongly influences the distance that contaminants migrate in groundwater (ESRD, 2014). Population density influences the adverse public response and PVD attributes. Rural population densities in Alberta range from 0 to 13 people per square kilometre (Statistics Canada, 2012).

\section{Well site prioritisation}

Given the required predictor information in Table 2 and OLR models for each attribute, well site prioritisation was completed. Well site classification allows a decision maker to focus first on
Predictors

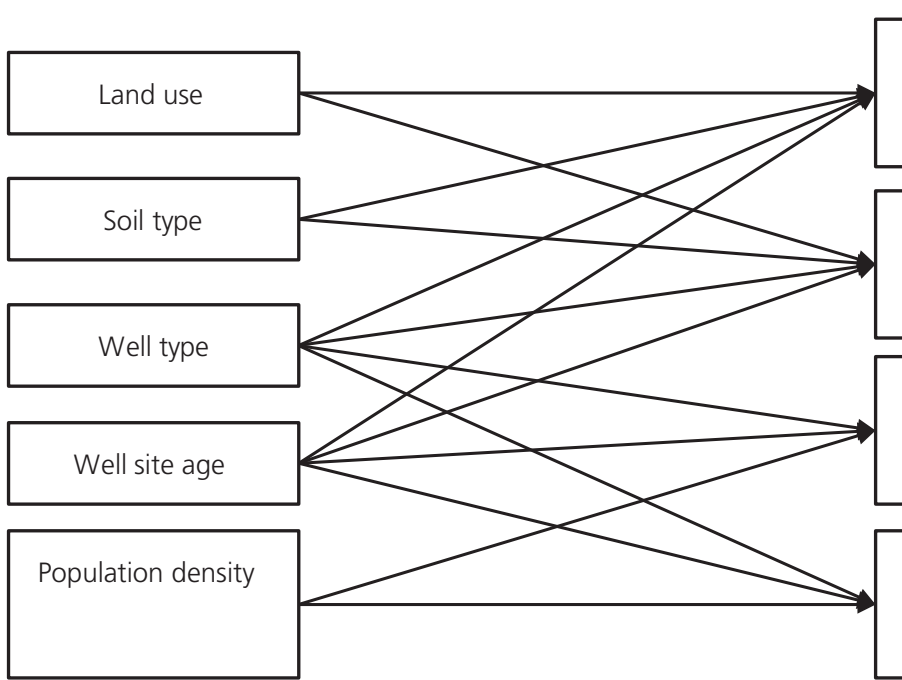

Outcomes

Adverse receptor effect classes

Environmental liability class

Adverse public response class

Property value diminution class

Figure 2. Attribute class prediction 


\begin{tabular}{lllll}
\hline Land use & Soil type & Well type & Well site age & Population density \\
\hline Agricultural & Coarse & Drilled and abandoned & Before 1975 & $<0 \cdot 5 / \mathrm{km}^{2}$ \\
Natural area & Fine & Crude oil production & $1975-1995$ & $0 \cdot 5$ to $<1$ per $\mathrm{km}^{2}$ \\
& & Natural gas production & 1996 to present & 1 to $<5{\mathrm{per} \mathrm{km}^{2}}^{2}$ \\
& & & & 5 to $<15$ per $\mathrm{km}^{2}$
\end{tabular}

Table 2. Predictor variables and levels

high-priority sites, a form of triage. Adverse receptor effect, adverse public response and PVD are the three attribute groups beyond a licensee's discretionary control and are used in classification. Similar to the attribute classes, well sites are classified into high $\left(C_{\mathrm{s}}=4\right)$, moderate $\left(\mathrm{C}_{\mathrm{s}}=3\right)$, low $\left(\mathrm{C}_{\mathrm{s}}=2\right)$ and negligible $\left(\mathrm{C}_{\mathrm{s}}=1\right)$ priority for reclamation. The maximum attribute class defines the well site class as formalised in Equation $8 . \mathrm{C}_{\mathrm{AE}_{\mathrm{k}}}, \mathrm{C}_{\mathrm{PR}}$ and $\mathrm{C}_{\mathrm{PVD}}$ are the mode classes of each OLR model's output.

8.

$$
\mathrm{C}_{\mathrm{s}}=\left(\bigvee_{\mathrm{k}} \mathrm{C}_{\mathrm{AE}_{\mathrm{k}}}\right) \vee \mathrm{C}_{\mathrm{PR}} \vee \mathrm{C}_{\mathrm{PVD}}
$$

This approach may seem too conservative since a single attribute's class can govern the well site's class. However, Thiessen and Achari (2011) noted that one attribute often influences reclamation decisions.

Following classification, well site ranking is performed to refine the prioritisation. The following conceptual benefit-cost equation guides this prioritisation
Reduction in:

Adverse receptor effect + 9. $\frac{\text { Benefit }}{\text { Cost }}=\frac{\text { Adverse public response }+ \text { PVD }}{\text { Environmental liability reduction }}$

The reductions stated in Equation 9 are class reductions (e.g. Class 4 to Class 1). The premise is to first allocate budget where the greatest reduction in negative environmental, social and economic impact will be achieved. Assuming Class 1 is desired for all attributes in the numerator after reclamation, the difference between the class-probability-weighted mean attribute class and desired class is used as an indicator of reclamation benefit. This difference, $\Delta \mathrm{C}_{\mathrm{AE}_{\mathrm{k}}}$ or $\Delta \mathrm{C}_{\mathrm{PR}}$ or $\Delta \mathrm{C}_{\mathrm{PVD}}$, divided by the difference in environmental liability, $\Delta \mathrm{C}_{\mathrm{EL}}$, after remediation is a quotient. For simplicity, $\Delta \mathrm{C}_{\mathrm{att}}$ represents $\Delta \mathrm{C}_{\mathrm{AE}_{\mathrm{k}}}, \Delta \mathrm{C}_{\mathrm{PR}}$ or $\Delta \mathrm{C}_{\mathrm{PVD}}$ and the quotient, $\mathrm{Quo}_{\mathrm{att}}=\Delta \mathrm{C}_{\mathrm{att}} /$ $\Delta \mathrm{C}_{\mathrm{EL}}$. This quotient is used in ranking sites.

Attribute preferences are accommodated in the ranking method. These preferences are compared pairwise and summarised in an

\begin{tabular}{|c|c|c|c|c|c|c|c|c|c|c|c|c|c|c|c|c|c|c|}
\hline \multirow{3}{*}{$\begin{array}{l}\text { Class probabilities } \\
p\left(C_{\text {att }}\right)\end{array}$} & \multicolumn{15}{|c|}{ Adverse receptor effect } & \multirow[b]{3}{*}{ 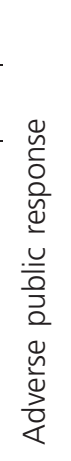 } & \multirow{3}{*}{\multicolumn{2}{|c|}{ 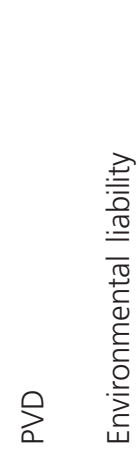 }} \\
\hline & \multicolumn{7}{|c|}{ Terrestrial receptor } & \multicolumn{8}{|c|}{ Aquatic receptor } & & & \\
\hline & $\begin{array}{l}\text { 乞 } \\
\stackrel{N}{0} \\
\stackrel{5}{J} \\
\text { I }\end{array}$ & $\begin{array}{l}\stackrel{\frac{n}{C}}{\frac{0}{0}} \\
\frac{0}{2}\end{array}$ & 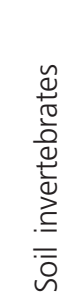 & $\begin{array}{l}\frac{n}{\sigma} \\
\sum^{E} \\
\frac{E}{\sigma} \\
\sum\end{array}$ & $\frac{n}{\overline{0}}$ & $\begin{array}{l}\frac{n}{c} \\
\frac{.0}{0} \\
\frac{\bar{O}}{\bar{c}} \\
\frac{O}{E} \\
\frac{\varepsilon}{4}\end{array}$ & 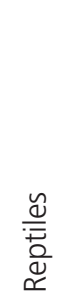 &  & 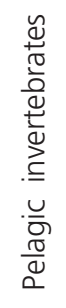 & 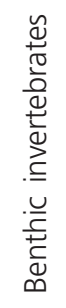 & $\frac{c}{i \frac{n}{4}}$ & $\begin{array}{l}\frac{n}{\widetilde{N}} \\
\stackrel{E}{E} \\
\frac{\tilde{\sigma}}{\tilde{N}} \\
\Sigma\end{array}$ & $\frac{n}{\overline{0}}$ & 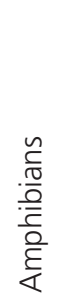 & $\frac{\tilde{c}}{\frac{\tilde{a}}{\mathscr{a}}}$ & & & \\
\hline $\operatorname{High}\left(C_{a t t}=4\right)$ & $0 \cdot 5$ & 0.3 & 0 & 0 & $0 \cdot 5$ & $0 \cdot 3$ & 0 & . & $0 \cdot 5$ & $0 \cdot 3$ & 0 & 0 & 0.5 & $0 \cdot 3$ & 0 & . & $0 \cdot 3$ & $0 \cdot 5$ \\
\hline Moderate $\left(C_{a t t}=3\right)$ & $0 \cdot 3$ & 0.5 & $0 \cdot 2$ & $0 \cdot 2$ & $0 \cdot 3$ & 0.5 & $0 \cdot 2$ & $0 \cdot 2$ & 0.3 & 0.5 & $0 \cdot 2$ & $0 \cdot 2$ & $0 \cdot 3$ & $0 \cdot 5$ & $0 \cdot 2$ & 0.2 & $0 \cdot 5$ & $0 \cdot 3$ \\
\hline $\operatorname{Low}\left(C_{\text {att }}=2\right)$ & $0 \cdot 2$ & 0.2 & 0.5 & 0.3 & 0.2 & 0.2 & $0 \cdot 5$ & $0 \cdot 3$ & $0 \cdot 2$ & $0 \cdot 2$ & 0.5 & $0 \cdot 3$ & $0 \cdot 2$ & $0 \cdot 2$ & 0.5 & 0.5 & $0 \cdot 2$ & $0 \cdot 2$ \\
\hline Negl. $\left(C_{a t t}=1\right)$ & 0 & 0 & $0 \cdot 3$ & 0.5 & 0 & 0 & $0 \cdot 3$ & $0 \cdot 5$ & 0 & 0 & $0 \cdot 3$ & 0.5 & 0 & 0 & $0 \cdot 3$ & 0.3 & 0 & 0 \\
\hline Mode class & 4 & 3 & 2 & 1 & 4 & 3 & 2 & 1 & 4 & 3 & 2 & 1 & 4 & 3 & 2 & 2 & 3 & - \\
\hline Mean class & $3 \cdot 3$ & $3 \cdot 1$ & 1.9 & $1 \cdot 7$ & $3 \cdot 3$ & $3 \cdot 1$ & 1.9 & $1 \cdot 7$ & $3 \cdot 3$ & $3 \cdot 1$ & 1.9 & $1 \cdot 7$ & $3 \cdot 3$ & $3 \cdot 1$ & 1.9 & 1.9 & $3 \cdot 1$ & $3 \cdot 3$ \\
\hline Desired class & 1 & 1 & 1 & 1 & 1 & 1 & 1 & 1 & 1 & 1 & 1 & 1 & 1 & 1 & 1 & 1 & 1 & 1 \\
\hline Difference, $\Delta C_{\text {att }}$ & $2 \cdot 3$ & $2 \cdot 1$ & 0.9 & 0.7 & $2 \cdot 3$ & $2 \cdot 1$ & 0.9 & 0.7 & $2 \cdot 3$ & $2 \cdot 1$ & 0.9 & $0 \cdot 7$ & $2 \cdot 3$ & $2 \cdot 1$ & 0.9 & 0.9 & $2 \cdot 1$ & $2 \cdot 3$ \\
\hline Quotient, Quoatt & $1 \cdot 0$ & 0.9 & $0 \cdot 4$ & $0 \cdot 3$ & $1 \cdot 0$ & 0.9 & 0.4 & 0.3 & $1 \cdot 0$ & 0.9 & 0.4 & $0 \cdot 3$ & $1 \cdot 0$ & 0.9 & 0.4 & 0.4 & 0.9 & - \\
\hline
\end{tabular}

Table 3. Well site-specific probabilities and statistics 
...Attribute $b$

Adverse receptor effect

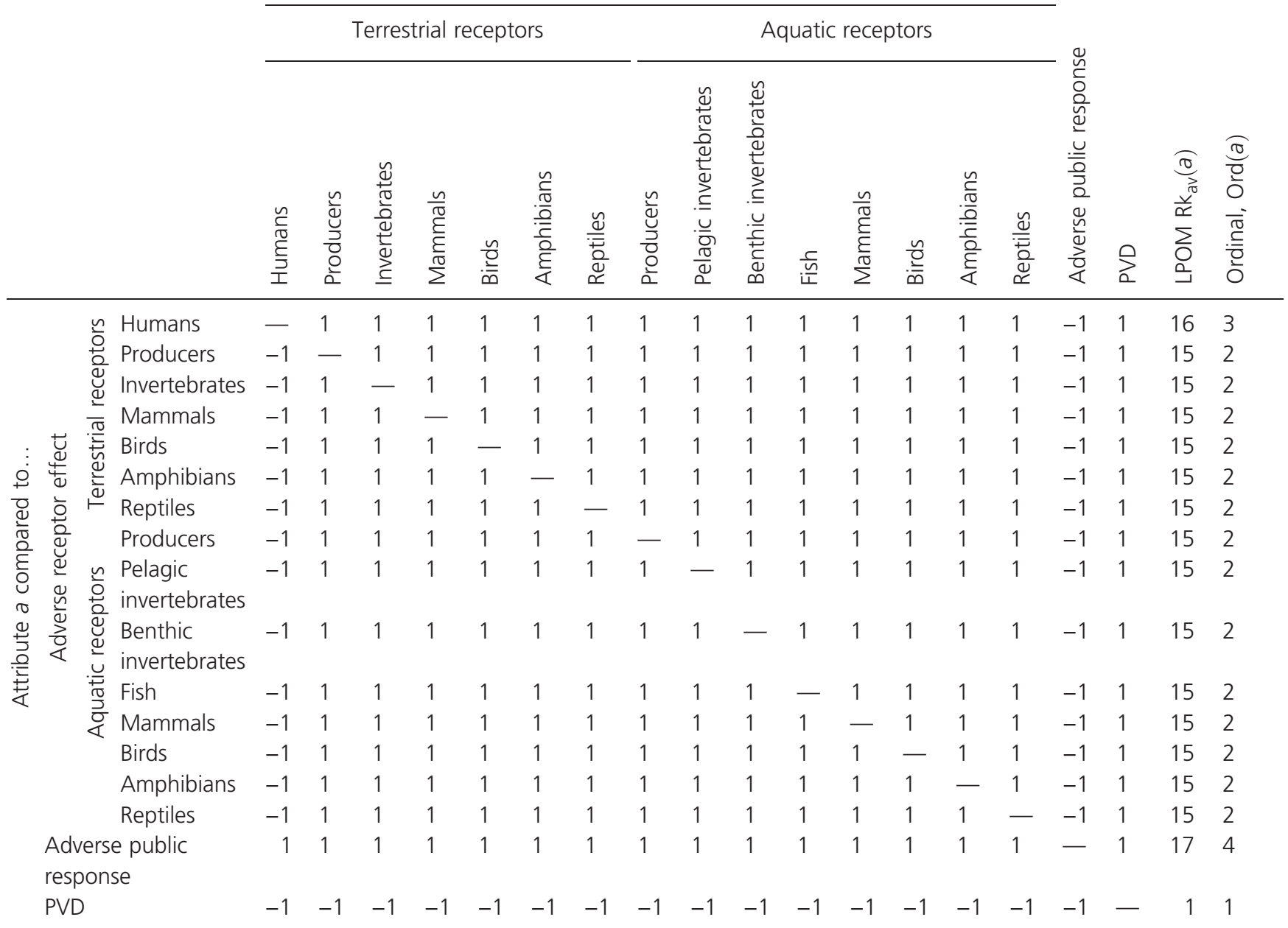

Table 4. Attribute preferences matrix

attribute preference matrix. If attribute $a$ is more important or equivalent to attribute $b, a \geq b$, the intersecting cell entry is 1 . The corollary entry is -1 if attribute $a$ is less important than attribute $b$. From this matrix, a preference order can be established using the computationally efficient local partial order model (LPOM) developed by Bruggemann et al. (2004), advanced by Carlsen (2008), and applied by Thiessen and Achari (2014)

10.

$$
\mathrm{Rk}_{\mathrm{av}}(a)=\frac{[\sup (a)+1]\left[\mathrm{N}_{\mathrm{k}}+1\right]}{\mathrm{N}_{\mathrm{att}}+1-\operatorname{inc}(a)}
$$

$\mathrm{N}_{\text {att }}$ is the number of attributes; $\sup (a)$ is the number of attribute comparisons where attribute $a$ is superior to attribute $b$ (i.e. the number of 1 entries in a row); and $\operatorname{inc}(a)$ is the number of attributes not comparable to attribute $a$ (i.e. the number of zeros in a row).

Given the attribute preferences, partial ordering of the well sites is determined using the logic in Equation 11, an extension of the non-biased ranking logic presented by Mauri and Ballabio (2008).

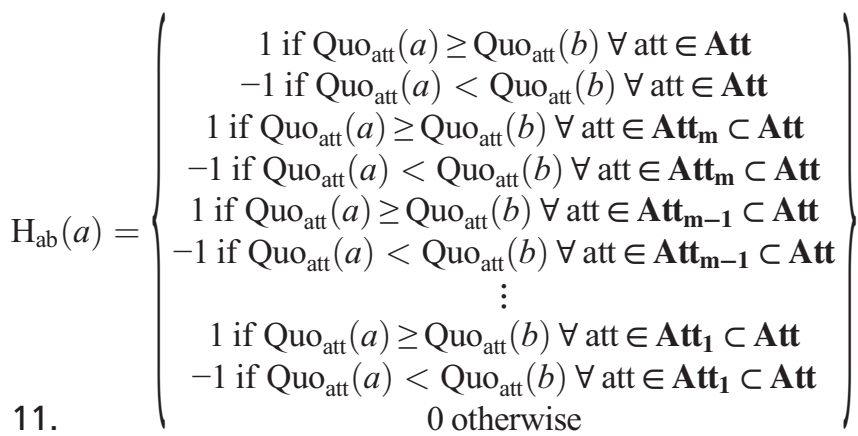




\begin{tabular}{|c|c|c|c|c|c|c|c|c|c|c|c|c|c|c|c|c|c|}
\hline \multirow[t]{3}{*}{ Site } & \multicolumn{15}{|c|}{ Adverse receptor effect } & \multirow[b]{3}{*}{ 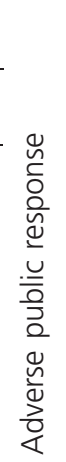 } & \multirow[b]{3}{*}{$\stackrel{0}{2}$} \\
\hline & \multicolumn{7}{|c|}{ Terrestrial receptors } & \multicolumn{8}{|c|}{ Aquatic receptors } & & \\
\hline & 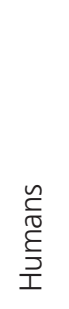 & 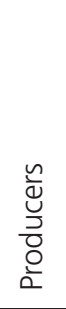 & 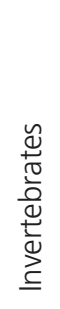 & $\begin{array}{l}\frac{\sim}{\sigma} \\
\varepsilon \\
\varepsilon \\
\frac{\sigma}{\tilde{\sigma}} \\
\Sigma\end{array}$ & $\frac{n}{0}$ & $\begin{array}{l}\frac{n}{\frac{1}{0}} \\
\frac{\sqrt{0}}{0} \\
\frac{\bar{Z}}{2} \\
\frac{2}{\varepsilon} \\
\frac{\varepsilon}{4}\end{array}$ & 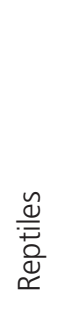 & $\begin{array}{l}\frac{n}{d} \\
\frac{\partial}{0} \\
\frac{0}{0} \\
\frac{0}{0}\end{array}$ & 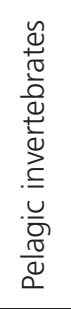 & 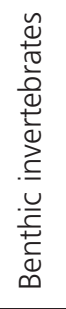 & $\frac{\bar{c}}{\underline{\underline{4}}}$ & $\begin{array}{l}\frac{n}{\widetilde{N}} \\
\stackrel{\varepsilon}{\varepsilon} \\
\frac{\varepsilon}{\Sigma} \\
\Sigma\end{array}$ & $\frac{n}{\overline{0}}$ & 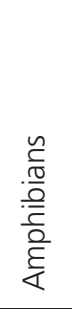 & 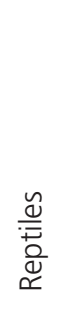 & & \\
\hline 1 & 0.9 & 0.8 & 0.9 & 0.9 & 0.9 & 1 & 1 & 0.9 & 0.9 & 0.9 & 0.8 & 1 & 1 & 0.9 & 1 & 1 & 0.8 \\
\hline 2 & 0.9 & 0.8 & 0.9 & 0.6 & 1 & 0.9 & 0.9 & 0.9 & 0.9 & 0.9 & 0.7 & 0.9 & 1 & $0 \cdot 1$ & 0.5 & $0 \cdot 3$ & 0.7 \\
\hline 3 & 0.7 & 0.8 & 0.9 & 0.6 & 0.5 & 0.8 & 0.9 & 0.8 & 0.8 & $0 \cdot 8$ & 0.6 & 0.7 & 0.6 & $0 \cdot 1$ & $0 \cdot 1$ & 0.5 & 0.6 \\
\hline 4 & 0.7 & 0.8 & 0.8 & 0.5 & 0.6 & 0.8 & 0.8 & $0 \cdot 8$ & 0.6 & $0 \cdot 7$ & 0.5 & 0.7 & 0.6 & 0.9 & 1 & 0.9 & 0.6 \\
\hline 5 & 0.7 & 0.8 & 0.8 & 0.4 & $0 \cdot 4$ & 0.6 & 0.8 & 0.6 & 0.6 & $0 \cdot 5$ & 0.5 & 0.7 & 0.5 & 0.8 & $0 \cdot 3$ & $0 \cdot 2$ & 0.5 \\
\hline 6 & 0.7 & 0.7 & 0.7 & 0.4 & 0.7 & 0.6 & 0.6 & 0.5 & 0.4 & 0.5 & 0.3 & 0.6 & 0.4 & 1 & 0.8 & 0.3 & 0.5 \\
\hline 7 & 0.5 & 0.6 & 0.7 & $0 \cdot 1$ & 0.7 & 0.4 & 0.6 & 0.5 & 0.3 & 0.4 & 0.3 & 0.2 & 0.3 & 0.9 & 0.9 & 0.6 & 0.4 \\
\hline 8 & 0.1 & 0.5 & 0.2 & 0.1 & 0.1 & 0.3 & 0.4 & 0.4 & 0.2 & 0.4 & 0.3 & 0.1 & 0.2 & 0.2 & 0.3 & 0.6 & 0.3 \\
\hline 9 & 0.1 & 0.3 & 0.1 & 0.1 & 0.1 & 0.1 & 0.3 & 0.1 & 0.2 & 0.2 & 0.1 & 0.1 & 0.2 & 0.2 & $0 \cdot 1$ & 0.1 & 0.1 \\
\hline 10 & 0.1 & 0.2 & 0.1 & $0 \cdot 1$ & $0 \cdot 1$ & $0 \cdot 1$ & 0.2 & $0 \cdot 1$ & 0.1 & $0 \cdot 1$ & 0.1 & 0.1 & 0.1 & 0.6 & 0.8 & 1 & 0.1 \\
\hline
\end{tabular}

Table 5. Site-specific Quoatt values

Att is the set of attributes and $\mathbf{A t t}_{\mathbf{m}}$ to $\mathbf{A t t}_{\mathbf{1}}$ are subsets of $\mathbf{A t t}$. These subsets are the preferred attribute groups in descending order. The first two rows in the equation state that given two sites, $a$ and $b$, if all attribute-specific quotients for site $a$ are greater than or equal to those for site $b$, assign a pairwise comparison value of 1 to the intersecting cell in the site ranking matrix. Alternately, if all quotients for site $a$ are lesser than those for site $b$, assign a value of -1 . If all the quotients for one site fail to dominate all those for the other site, the remaining rows in the equation apply. If no comparison is possible, a value of zero is assigned to the cell as per the last row in the equation.
A total order of the well sites is estimated by applying Equation 10 . $\mathrm{N}_{\text {att }}$ is replaced with the number of sites, $\mathrm{N}_{\mathrm{s}}$. There can be significant uncertainty in the total order if non-comparabilities exist (i.e. zero entries). The following two equations provide the minimum and maximum value of a site's rank, respectively, in such cases (Bruggemann et al., 2004).

12. $\operatorname{Rk}_{\text {min }}(a)=\sup (a)+1$

13. $\mathrm{Rk}_{\max }(a)=\sup (a)+\operatorname{inc}(a)+1$

\begin{tabular}{|c|c|c|c|c|c|c|c|c|c|c|c|c|}
\hline & & \multicolumn{10}{|c|}{$\ldots$ Site $b$} & \multirow{2}{*}{$\begin{array}{l}\text { LPOM } \\
\mathrm{Rk}_{\mathrm{av}}(\mathrm{a})\end{array}$} \\
\hline & & 1 & 2 & 3 & 4 & 5 & 6 & 7 & 8 & 9 & 10 & \\
\hline \multirow{10}{*}{ 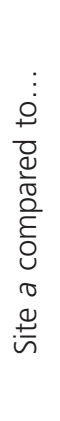 } & 1 & - & 1 & 1 & 1 & 1 & 1 & 1 & 1 & 1 & 1 & 10 \\
\hline & 2 & -1 & - & -1 & -1 & 1 & 1 & -1 & -1 & 1 & -1 & 4 \\
\hline & 3 & -1 & 1 & - & -1 & 1 & 1 & -1 & -1 & 1 & -1 & 5 \\
\hline & 4 & -1 & 1 & 1 & - & 1 & 1 & 1 & 1 & 1 & -1 & 8 \\
\hline & 5 & -1 & -1 & -1 & -1 & - & -1 & -1 & -1 & 1 & -1 & 2 \\
\hline & 6 & -1 & 1 & -1 & -1 & 1 & - & -1 & -1 & 1 & -1 & 4 \\
\hline & 7 & -1 & 1 & 1 & -1 & 1 & 1 & - & 1 & 1 & -1 & 7 \\
\hline & 8 & -1 & 1 & 1 & -1 & 1 & 1 & -1 & - & 1 & -1 & 6 \\
\hline & 9 & -1 & -1 & -1 & -1 & -1 & -1 & -1 & -1 & - & -1 & 1 \\
\hline & 10 & -1 & 1 & 1 & 1 & 1 & 1 & 1 & 1 & 1 & - & 9 \\
\hline
\end{tabular}

Table 6. Site ranking matrix 
Journal of Environmental Engineering and

Science

Volume 10 Issue JS3
A well site reclamation prioritisation

model framework

Thiessen and Achari

\section{Case study}

A case study illustrates the classification and ranking method described above. Table 3 is information on a well site. The first four data rows in the table are class probabilities, determined by OLR, for each of the 18 attributes in the illustration. For each attribute, the mode probability defines the attribute's class. Applying Equation 8, the well site is Class 4.

Given a similar table for each of the ten well sites, the portfolio of the ten sites is also ranked. The following preference order was applied: adverse public response $>$ adverse human receptor effect $>$ adverse ecological receptor effect $>$ PVD. The preference matrix in Table 4 shows how this order was derived. The second last column in the table is the average rank of attribute $a, \operatorname{Rk}_{\mathrm{av}}(a)$, calculated using Equation 10.

Given the attribute preferences in Table 4 and the Quo $_{\text {att }}$ values in Table 5 for the ten well sites, well site ranking was performed. Applying Equation 11 to the data in Table 5 yielded the partial site orders and total site order in Table 6 . The resulting remediation priority sequence is $1,10,4,7,8,3,2$ and 6,5 , and 9 in descending order based on $\operatorname{Rk}_{\mathrm{av}}(a)$. In the illustration, there were no noncomparables, meaning Equation 12 and Equation 13 were not required.

\section{Conclusions}

This article describes a model for oil and gas well site remediation prioritisation in terms of negative environmental, economic and social impacts. The model takes a holistic approach and considers adverse environmental receptor effects, adverse public response, environmental liability and PVD to prioritise oil and gas well sites for reclamation. The inter-relationships of these factors are introduced and a case study of site ranking is presented.

The authors acknowledge and appreciate research funding received from The University of Calgary, Manulife Financial, and Engineers Canada.

\section{REFERENCES}

AEP (Alberta Environment and Parks) (2015) Oil and Gas Wells Reclamation. AEP, Edmonton, AB, Canada. See http://esrd. alberta.ca/focus/state-of-the-environment/land/responseindicators/oil-and-gas-wells-reclamation.aspx (accessed 19/08/ 2015).

AER (Alberta Energy Regulator) (2014a) Upstream Oil and Gas Reclamation \& Remediation Program. AER, Calgary, AB, Canada. See http://www.aer.ca/abandonment-and-reclamation/ upstream-oil-gas-recrem-program (accessed 19/08/2015).

AER (2014b) Assessing Drilling Waste Disposal Areas: Compliance Options for Reclamation Certification. AER, Calgary, AB, Canada. See http://www.aer.ca/documents/ liability/AssessingDrillingDisposaAreas.pdf (accessed 19/08/ 2015).

AER (2014c) Directive 060: Upstream Petroleum Industry Flaring, Incinerating, and Venting. AER, Calgary, AB,
Canada. See http://www.aer.ca/documents/directives/ Directive060 April2014.pdf (accessed 19/08/2015). AER (2015) ST37: List of Wells in Alberta. AER, Calgary, AB, Canada. See http://www.aer.ca/data-and-publications/ statistical-reports/st37 (accessed 19/08/2015).

AIC (Appraisal Institute of Canada) (2010) Appraisal of Real Estate, 3rd edn. University of British Columbia, Vancouver, $\mathrm{BC}$, Canada.

ASB (Appraisal Standards Board) (2013) Advisory opinion 9: the appraisal of real property that may be impacted by environmental contamination. In USPAP Advisory Opinions, 2014-2015 edn. Appraisal Foundation, Washington, DC, USA, pp. A-16-A-20. See http://www.uspap.org/ (accessed 19/08/2015).

Bell R, Anderson OC and Sanders MV (2008) Real Estate Damages: Applied Economics and Detrimental Conditions, 2nd edn. Appraisal Institute, Chicago, IL, USA.

Bruggemann R, Sorensen PB, Lerche D and Carlsen L (2004) Estimation of averaged ranks by a local partial order model. Journal of Chemical Information and Computer Sciences 44(2): 618-625, http://dx.doi.org/10.1021/ci034214m.

Carlsen L (2008) Hierarchical partial order ranking. Environmental Pollution 155(2): 247-253, http://dx.doi.org/ 10.1016/j.envpol.2007.11.023.

CCME (Canadian Council of Ministers of the Environment) (1996) PN 1195: A Framework for Ecological Risk Assessment: General Guidance. CCME, Winnipeg, MB, Canada. See http://www.ccme.ca/files/Resources/csm/ pn_1195_e.pdf (accessed 19/08/2015).

CCME (1997) PN 1274: A Framework for Ecological Risk Assessment: Technical Appendices, CCME, Winnipeg, MB, Canada. See http://www.ccme.ca/files/Resources/csm/ pn_1274_e.pdf (accessed 19/08/2015).

CCME (2006a) PN 1332: A Protocol for the Derivation of Environmental and Human Health Soil Quality Guideline. CCME, Winnipeg, MB, Canada. See http://www.ccme.ca/ files/ceqg/en/sg_protocol_1332_e.pdf (accessed 19/08/2015).

CCME (2006b) PN 1361: Recommended Principles on Contaminated Site Liability. CCME, Winnipeg, MB, Canada. See http://www.ccme.ca/files/Resources/csm/ csl 14 principles_e.pdf (accessed 19/08/2015).

CCME (2015) PN 1533: A Protocol for the Derivation of Groundwater Quality Guidelines for Use at Contaminated Sites. CCME, Winnipeg, MB, Canada. See http://ceqg-rcqe. ccme.ca/download/en/348 (accessed 19/08/2015).

CEAA (Canadian Environmental Assessment Agency) (2012) Determining Whether a Project is Likely to Cause Significant Adverse Environmental Effects. CEAA, Ottawa, ON, Canada. See http://www.ceaa-acee.gc.ca/default.asp? lang=En\&n=D213D286-1\&offset=2\&toc=show (accessed 19/08/2015).

CPA Canada (Chartered Professional Accountants of Canada) (2014) IAS 37: Provisions, contingent liabilities and contingent assets. In CPA Canada Handbook - Accounting 
Journal of Environmental Engineering and

Science

Volume 10 Issue JS3
A well site reclamation prioritisation

model framework

Thiessen and Achari
(CPACACC), Part I - International Financial Reporting Standards, Update 28. CPA Canada, Toronto, ON, Canada.

Environment Canada (2012) Federal Contaminated Sites Action Plant (FCSAP), Ecological Risk Assessment Guidance. Environment Canada, Ottawa, ON, Canada. See http://www. federalcontaminatedsites.gc.ca/B15E990A-C0A8-4780-912407650F3A68EA/ERA\%20Guidance $\% 2030 \% 20$ March $\%$ 202012_FINAL_En.pdf (accessed 19/08/2015).

ERCB (Energy Resources Conservation Board) (2012) Directive 001: Requirements for Site-Specific Liability Assessments in Support of the ERCB's Liability Management Programs. ERCB, Calgary, AB, Canada. See https://www.aer.ca/ documents/directives/Directive001.pdf (accessed 19/08/2015).

ESRD (Alberta Environment and Sustainable Resource Development) (2013) 2010 Reclamation Criteria for Wellsites and Associated Facilities for Cultivated Lands. ESRD, Edmonton, AB, Canada. See http://esrd.alberta.ca/landsforests/land-industrial/programs-and-services/reclamation-andremediation/upstream-oil-and-gas-reclamation-andremediation-program/documents/2010-ReclamationCriteriaCultivatedLands.pdf (accessed 19/08/2015).

ESRD (2014) Alberta Tier 1 Soil and Groundwater Remediation Guidelines. ESRD, Edmonton, AB, Canada. See http://esrd. alberta.ca/lands-forests/land-industrial/inspections-andcompliance/documents/AlbertaTier1Guidelines-May23-2014. pdf (accessed 19/08/2015).

ESRD (2015) Email from Gordon Dinwoodie, Land Reclamation Specialist at ESRD, to Ron Thiessen, Doctoral Candidate at University of Calgary, Regarding Update on Post-Abandonment Reclamation Timelines. ESRD, Edmonton, AB, Canada.

Health Canada (2010) Federal Contaminated Site Risk Assessment in Canada, Part V: Guidance on Human Health Detailed Quantitative Risk Assessment for Chemicals. Health Canada, Ottawa, ON, Canada. See http://www.hc-sc.gc.ca/ ewh-semt/pubs/contamsite/chem-chim/index-eng.php (accessed 19/08/2015).

Health Canada (2011) Federal Contaminated Site Risk Assessment in Canada, Part IV: Spreadsheet Tool for Human Health Preliminary Quantitative Risk Assessment (PQRA). Health Canada, Ottawa, ON, Canada.

Hosmer DW, Lemeshow S and Sturdivant RX (2013) Applied Logistic Regression, 3rd edn. Wiley, Hoboken, NJ, USA.

ISO (International Organisation for Standardisation) (2010) ISO 26000:2010: Guidance on Social Responsibility. ISO, Geneva, Switzerland.

Kasperson JX, Kasperson RE, Pidgeon N and Slovic P (2003) The social amplification of risk: assessing fifteen years of research and theory. In The Social Amplification of Risk (Pidgeon N, Kasperson RE and Slovic P (eds)). Cambridge University Press, Cambridge, UK, pp. 13-46.

Kraus N, Malmfors T and Slovic P (1992) Intuitive toxicology: expert and lay judgments of chemical risks. Risk Analysis 12(2): 215-232, http://dx.doi.org/10.1111/j.1539-6924.1992. tb00669.x.
Krewski D, Turner MC, Lemyre L and Lee JE (2012) Expert vs. public perception of population health risks in Canada. Journal of Risk Research 15(6): 601-625, http://dx.doi.org/ 10.1080/13669877.2011.649297.

Kutner MH, Nachtsheim CJ, Neter J and Li W (2005) Applied Linear Statistical Models, 5th edn. McGraw-Hill, Singapore.

Lazo JK, Kinnell JC and Fisher A (2000) Expert and layperson perceptions of ecosystem risk. Risk Analysis 20(2): 179-193, http://dx.doi.org/10.1111/0272-4332.202019.

Mauri A and Ballabio D (2008) Similarity/diversity measure for sequential data based on Hasse matrices; theory and applications. In Data Handling in Science and Technology: Scientific Data Ranking Methods: Theory and Applications (Pavan M and Todeschini R (eds)). Elsevier, Oxford, UK, pp. 111-138.

Mertz CK, Slovic P and Purchase IF (1998) Judgments of chemical risks: comparisons among senior managers, toxicologists, and the public. Risk Analysis 18(4): 391-404, http://dx.doi.org/ 10.1111/j.1539-6924.1998.tb00353.x.

NEB (National Energy Board) (2014) NEB Event Reporting Guidelines. NEB, Calgary, AB, Canada. See https://www.nebone.gc.ca/bts/ctrg/gnnb/rprtnggdlns/vntrprtnggdln-eng.pdf (accessed 19/08/2015).

Neil N, Malmfors T and Slovic P (1994) Intuitive toxicology: expert and lay judgments of chemical risks. Toxicologic Pathology 22(2): 198-201, http://dx.doi.org/10.1177/ 019262339402200214.

Nguyen HT and Walker EA (2006) A First Course in Fuzzy Logic, 3rd edn. Chapman and Hall, Boca Raton, FL, USA.

Norusis MJ (2007) SPSS 15.0 Advanced Statistical Procedures Companion. Prentice-Hall, Upper Saddle River, NJ, USA.

Robinson B (2010) Well abandonment and reclamation in Alberta: the failure of the licensee liability rating program. Well \& Pipeline Abandonment, Suspension and Reclamation Conference Proceedings. Canadian Institute, Calgary, AB, Canada.

Slovic P, Malmfors T, Krewski D et al. (1995) Intuitive toxicology. II. Expert and lay judgments of chemical risks in Canada. Risk Analysis 15(6): 661-675, http://dx.doi.org/10.1111/ j.1539-6924.1995.tb01338.x.

Statistics Canada (2012) Population and Dwelling Counts, for Canada, Provinces and Territories, and Census Subdivisions (Municipalities), 2011 and 2006. See http://www12.statcan. gc.ca/census-recensement/2011/dp-pd/hlt-fst/pd-p1/File.cfm? $\mathrm{T}=302 \& \mathrm{SR}=1 \& \mathrm{RPP}=9999 \& \mathrm{PR}=48 \& \mathrm{CMA}=0 \& \mathrm{~S}=51 \& \mathrm{O}=$ A\&LANG=Eng\&OFT=CSV (accessed 19/08/2015).

Tabachnick BG and Fidell LS (2012) Using Multivariate Statistics, 6th edn. Pearson, Upper Saddle River, NJ, USA.

Thiessen RJ and Achari G (2011) A comparison of 2008 national classification system for contaminated sites scores to preliminary quantitative risk assessment hazard quotients. Canadian Journal of Civil Engineering 38(7): 719-728, http://dx.doi.org/10.1139/111-039. 
Journal of Environmental Engineering and Science

Volume 10 Issue JS3
A well site reclamation prioritisation

model framework

Thiessen and Achari
Thiessen RJ and Achari G (2014) Application of partial orders and Hasse matrices in ranking contaminated sites. In Multiindicator Systems and Modelling in Partial Order (Bruggemann R, Carlsen L and Wittmann J (eds)). Springer, New York, NY, USA, pp. 253-274.
Unger J (2013) Reclaiming Tomorrow Today: Regulatory Timing for Abandonment and Reclamation of Well Sites in Alberta. Environmental Law Centre, Edmonton, AB, Canada. See http://www.elc.ab.ca/media/8918/Reclaiming_Tomorrow_ Today.pdf (accessed 19/08/2015).

\section{WHAT DO YOU THINK?}

To discuss this paper, please submit up to 500 words to the editor at journals@ice.org.uk. Your contribution will be forwarded to the author(s) for a reply and, if considered appropriate by the editorial panel, will be published as a discussion in a future issue of the journal. 